\title{
When Judges defy Dictators: \\ An Audience-Based Framework to Explain the Emergence of Judicial Assertiveness against Authoritarian regimes
}

\author{
Yasser Kureshi
}

\begin{abstract}
Under what conditions do judiciaries act assertively against authoritarian regimes? I argue that the judiciary coalesces around institutional norms and preferences in response to the preferences of institutions and networks, or "audiences," with which judges interact, and which shape the careers and reputations of judges. Proposing a typology of judicial-regime relations, I demonstrate that the judiciary's affinity to authoritarian regimes diminishes as these audiences grow independent from the regime. Using case law research, archival research and interviews, I demonstrate the utility of the audience-based framework for explaining judicial behavior in authoritarian regimes by exploring cross-temporal variation across authoritarian regimes in Pakistan. This study integrates ideas-based and interest-based explanations for judicial behavior in a generalizable framework for explaining variation in judicial assertiveness against.

authoritarian regimes.
\end{abstract}




\section{Introduction:}

How do we explain the emergence of judicial assertiveness in repressive environments? When judges challenge autocrats they do so knowing autocrats may very well retaliate. Despite the repressive capacity of authoritarian regimes, and the lack of institutional safeguards protecting judicial independence, judiciaries have shown the temerity to challenge those regimes in countries as diverse as Spain, Malaysia, Pakistan, and the Maldives, often risking their authority, positions, and sometimes even their freedom. ${ }^{1}$ In 2007, Pakistan's Supreme Court challenged the foundations of General Musharraf's regime in a series of landmark decisions, at a time when the regime was stable without any clear political opening or weakness to explain increasing judicial assertiveness. $^{2}$ Even when the regime slashed the powers of the judiciary, and attempted to coerce judges into pledging loyalty to the regime, a majority of judges refused to swear an oath, losing their positions and even facing detention. Such high-risk assertiveness defies the expectations of rational choice theories. Therefore, this article develops a framework to explain the development of judicial norms and preferences that motivate judicial assertiveness even against powerful autocrats. Understanding the processes shaping judicial assertiveness against authoritarian regimes provides critical insights into the ideas and interests underlying judicial behavior, and the conditions under which judiciaries can emerge as sources of resistance and opposition in authoritarian regimes.

Judicial assertiveness is manifested when courts challenge powerful actors through their rulings, i.e. when courts seek to nullify, restrict or change the behavior of actors through judicial decisions. ${ }^{3}$ Since high-risk judicial assertiveness cannot be reconciled with the motivation to protect the court's policymaking authority from authoritarian backlash, explaining high-risk judicial assertiveness against authoritarian regimes requires engaging with other interests of 
judges, including reputation building and job satisfaction, as well as the construction of judges' ideas and preferences. ${ }^{4}$ In-depth studies of judiciaries in individual states have shown that unique features of the institutional structure of the judiciary shape the ideas and interests of judges in authoritarian regimes. ${ }^{5}$ This article uses the Pakistan case to develop a theory to explain variation in judicial behavior across diverse authoritarian settings, and shed light on how formal and informal relationships between the regime and the judiciary shape the interests and ideas informing judicial behavior. ${ }^{6}$

I argue that the judiciary converges on a set of institutional norms and preferences in response to the preferences of the institutions and networks, or audiences, with which judges interact. ${ }^{7}$ Judicial behavior is shaped by both material interests, including the advancement of careers and furthering political authority, and non-material interests including esteem-building and job satisfaction. The critical audiences for the judiciary are i) institutions and organizations that impact judges' careers and ii) social and professional networks with which judges seek to build esteem.

Institutional interlinkages provide the regime or other actors the means to shape the internal structure and culture of judicial institutions. If the regime and its allies share institutional interlinkages with the judiciary, then the regime becomes a critical audience affecting the careers and esteem of judges, thus shaping the judicial norms and preferences underlying judicial behavior. I argue that variation in the institutional interlinkages between regime and judiciary will shape variation in judicial assertiveness against authoritarian regimes. As the regime's institutional interlinkages with the judiciary decrease, the regime's role as an audience shaping judicial norms and preferences decreases, and the judiciary is more likely to develop norms and preferences that clash with the regime, leading the judiciary to act assertively even against stable 
and repressive authoritarian regimes.

The audience-based framework highlights the importance of both formal institutional and informal network relationships in explaining judicial assertiveness and incorporates insights from political sociology into the study of judicial institutions. ${ }^{8}$ Further, it bridges the gap between the study of authoritarian strategy and judicial ideology by outlining an interactive framework that can explain both how judges develop norms and preferences in response to their relationship with regimes, and how autocrats develop institutional interlinkages to manipulate the interests of judges and ensure judicial values and preferences align with the regime.

In this article, I first discuss the literature on judicial behavior which this study contributes to, and then outline the audience-based framework. Based on this framework, I propose a typology of relationships between regimes and judiciaries that can explain variations in judicial assertiveness across different authoritarian regimes. Then I evaluate the audiencebased framework through a cross-temporal study of superior judiciaries under three authoritarian regimes in Pakistan. I conduct a close primary analysis of judiciary-regime relations in Pakistan, under three military rulers: Ayub Khan, Zia ul Haq, and Pervez Musharraf. The interlinkages between the regime and the judiciary vary across these regimes, as does judicial assertiveness towards the regimes. Pakistan provides an especially useful set of cases since the Pakistani judiciary was known to be the 'junior partner' of Ayub's regime, but emerged as the primary challenger to Musharraf 's regime facilitating a spectacular and successful democratization movement. For each period, I rely on the content of judicial decisions, information gleaned from newspaper archives and interviews with lawyers and judges. ${ }^{9}$ Using these sources of evidence, I show how variation in institutional interlinkages across the regimes explains loyal judicial support for military supremacy under Ayub, deferential support to military supremacy under Zia, 
and finally judicial competition with military supremacy under Musharraf. Finally, I briefly consider the generalizability of the audience-based framework to regimes beyond Pakistan.

\section{Judicial Assertiveness in Authoritarian Regimes:}

Scholars of judicial politics have demonstrated growing interest in understanding the emergence of assertive judiciaries outside the context of established democracies, including authoritarian and post-authoritarian states, where the political context shaping judicial decision- making is less fluid, and the institutional safeguards protecting judicial independence and authority are less secure. ${ }^{10}$

Interests-oriented explanations for judicial assertiveness hold that judges, motivated by the goal of realizing their policy preferences, will act on their sincere preferences when they can, but will adjust their behavior to minimize any risk to their authority to realize their policy preferences as closely as possible. ${ }^{11} \mathrm{~A}$ strategic judiciary would avoid risking losing its authority by asserting itself against an authoritarian regime, except when the regime's power is fragmented or a new political dispensation is imminent. ${ }^{12}$ Therefore, interests-based scholars cannot explain high risk judicial activism, where the judiciary risks likely retaliation when acting assertively, but does so anyway. ${ }^{13}$

Ideas-oriented scholars have largely focused on the way ideas shape judicial outcomes, examining how the institutional and political contexts embed judicial attitudes, normative principles, and notions about the proper role of courts in the institutional fabric of the judiciary, which then shape judicial behaviour. ${ }^{14}$ This scholarship provides useful guides for explaining the internalization of judicial norms and preferences through socialization, diffusion, learning and 
selection, all of which can influence judicial decision-making. ${ }^{15}$ Institutional settings guide the behaviour and expectations of judiciaries by determining both which actors have more or less power over judges, and which actors' norms and understandings of justice and rationality have primacy. ${ }^{16}$ This historical institutionalist literature can explain high-risk judicial activism by pointing to the entrenchment of judicial ideas that motivate judicial assertiveness even in unfavourable political environments. Yet ideas-oriented scholars tend to only explain judicial activity in particular domains or locations, rather than providing a systemized framework for explaining how ideas, institutions, and actors interact to contribute to understanding outcomes across multiple settings. ${ }^{17}$ What is needed is an explanation for judicial assertiveness that explains the possibility of high-risk judicial assertiveness and is generalizable across authoritarian regimes.

\section{Judicial Audiences in Authoritarian Regimes:}

I integrate ideas-oriented and interests-oriented approaches, using what Baum (2007) calls an "audience-based" perspective. ${ }^{18}$ Baum's audience-based perspective recognizes that judges do not merely seek good policy, and the authority to realize their understanding of good policy. Instead judges also value esteem from people with which they have relationships, for both material and non-material purposes. The judges' audiences, for the purposes of this discussion, could be political institutions, civil and political organizations or social and professional groupings, that are attentive to the decisions that judges make, and that judges, have reasons to seek approval or support from, when making decisions. The reasons judges seek approval from these audiences include judges' material interests (including the advancement of their careers) 
and non-material interests (including the desire for esteem building and job satisfaction). ${ }^{19}$ According to the audience-based perspective, this pursuit of approval from judicial audiences for both material and non-material purposes shapes judicial behavior.

Judges do not simply get to pick and choose their audiences based on their preferences. ${ }^{20}$ Instead, different institutional designs connect the judiciary formally and informally to different audiences. ${ }^{21}$ Institutional interlinkages are defined as links to the internal rules and processes of the judiciary that allow external actors to shape the internal structure and culture of the institution. The institutions, organizations, and networks that sustain institutional interlinkages with the judiciary are the critical audiences for the judiciary ${ }^{22}$

If the regime or affiliated allies have a role in appointments, promotions, and disciplining of judges, I describe this as a utilitarian interlinkage with the judiciary, as attention to regime preferences is essential to a judge's career advancement and security. If the social and professional networks that serve as recruitment feeders for the judiciary are tied to or benefit from the regime, then the regime possesses normative interlinkages with the judiciary, as attention to regime preferences is essential to a judges' professional esteem within his or her network.

Authoritarian regimes vary in the degree to which they sustain utilitarian and normative interlinkages with the judiciary. This variation determines the degree to which the authoritarian regime constitutes the dominant audience shaping the norms and preferences underlying judicial behavior. ${ }^{23}$ Where the regime constitutes the dominant audience, only judges who sincerely share or strategically endorse the preferences and values of the regime will advance their careers and enhance their esteem. Thus, the regime can ensure that norms and preferences underlying judicial behavior align with the regime's interests. In its decisions, the judiciary can support the 
regime either by legitimizing the political agenda of the regime, or by deferring to the actions and authority of the regime. Alternatively, it can act assertively against the regime by challenging the regime's agenda and authority in its decisions. To capture this variation in regime-judicial interlinkages and its impact on judicial behavior towards the regime, I propose a four-part typology. Each configuration of regime-judicial interlinkages should result in a varied mix of judicial deference, legitimization, and assertiveness, but with one form of judicial behavior more common than the others.

Table 1: A Typology of Judicial Relationships with Authoritarian Regimes

\begin{tabular}{|c|c|c|c|}
\hline & \multicolumn{3}{|c|}{ Normative Interlinkages } \\
\hline \multirow{3}{*}{$\begin{array}{l}\text { Utilitarian } \\
\text { Interlinkages }\end{array}$} & & $\begin{array}{l}\text { Yes } \\
\text { (Social and/or Professional } \\
\text { Networks are Recruited } \\
\text { from are Aligned with the } \\
\text { Regime) }\end{array}$ & $\begin{array}{l}\text { No } \\
\text { (Social and/or Professional } \\
\text { Network Judges are Recruited } \\
\text { from are not Aligned with the } \\
\text { Regime) }\end{array}$ \\
\hline & $\begin{array}{l}\text { Yes } \\
\text { (Appointing } \\
\text { Authority/s Aligned } \\
\text { with the Regime) }\end{array}$ & $\begin{array}{l}\text { Loyal Court } \\
\text { (Support for the Regime's } \\
\text { Agenda and Deference to its } \\
\text { Authority) }\end{array}$ & $\begin{array}{l}\text { Controlled Court } \\
\text { (Deference to the Regime's } \\
\text { Authority) }\end{array}$ \\
\hline & $\begin{array}{l}\text { No } \\
\text { (Appointing } \\
\text { Authority/s } \\
\text { Independent from } \\
\text { the Regime) }\end{array}$ & $\begin{array}{l}\text { Collaborative Court } \\
\text { (Support for the Regime's } \\
\text { Agenda) }\end{array}$ & $\begin{array}{l}\text { Competitive Court } \\
\text { (Assertiveness Against the } \\
\text { Regime) }\end{array}$ \\
\hline
\end{tabular}

A Controlled Court shares utilitarian interlinkages with the ruling coalition of the regime, i.e. regime officials or their allies govern the career trajectory of judges, through the 
appointment, removal, promotion, and disciplining processes common to all judiciaries. Where the regime shapes the career advancement of judges, it will recruit judges who either support the regime or are, at least, risk-averse and pliable enough to avoid challenging the regime. Hence, a controlled court will be characterized primarily by a pattern of deferential support to the regime where the judiciary reads its jurisdiction narrowly, avoiding taking up litigation challenging the regime, and refraining from intervening in the actions of the regime when it does.

A Collaborative Court shares normative interlinkages with the regime, i.e. the judiciary comprises judges recruited from social and professional networks that benefit from, and are supportive of, the regime. The idea that the social and professional sources of judicial recruitment shape the values and ideals of these judges is well established among law and society scholars. ${ }^{24}$ Woods (2009) highlights how the communities or networks in which judges are embedded, shape the thinking of judges through processes of informal interactions. ${ }^{25}$ Judges train, work and socialize with these networks prior to being appointed, and continue to be embedded within these networks even after being appointed. These networks shape judges' perceptions of what are acceptable and unacceptable actions for judges to take. For example, networks of state bureaucrats that depend on regime support and are disconnected from civil society may be more inclined to endorse deference to executive institutions. Alternatively, politically active, self-regulatory bar associations may be less tied to the regime, and therefore less inclined to support an authoritarian executive. It is not inevitable that judges recruited from bar associations are necessarily assertive, or judges recruited from the judicial bureaucracy are necessarily deferential. Bar associations can be coopted or controlled by an authoritarian regime, and state bureaucracies may maintain autonomy and preserve their own institutional values. Therefore, it is important to understand the social and professional networks judges come from, 
and the ideological milieu legal practitioners engage with through their education, occupations and social and professional interactions in potential pathways to the superior judiciary.

When the judiciary is recruited from, and embedded in, a professional network that is tied to, and supportive of, the regime, we should see a collaborative judiciary, as judges are socialized to support the agenda of the regime, and their esteem with these networks would suffer from challenging or delegitimizing the state. Hence, collaborative courts will be characterized by a pattern of legitimization of the regime's agenda, where the judiciary will take up litigation challenging the regime, and rule in favour of the regime, articulating a legal rationale that legitimizes the agenda of the regime.

In the Loyal Court, the regime has both utilitarian and normative interlinkages with the judiciary, as the key audience/s that control the career path of judges are aligned with or include the regime and its affiliated elites, and the judges are recruited from networks that are aligned with the regime. The loyal court's jurisprudence is characterized by deference to the authority of the regime and legitimization of its agenda. The judiciary will read its own powers and jurisdiction narrowly to provide the regime maximum autonomy, and where the judiciary takes up litigation, it will rule in the regime's favour, legitimizing the regime's actions and agenda.

In the Competitive Court, the regime and the judiciary enjoy no institutional interlinkages and thus the regime cannot shape the norms and preferences of the judiciary. The competitive court will not see itself as deferential to the regime nor share the regime's ideological agenda. It is less likely to read its powers narrowly to avoid challenging the regime, or to uphold the agenda of the regime. Instead, the Competitive Court will develop norms and preferences that differ from the regime, and where their interests and ambitions clash, it is more likely to compete and clash with the regime. 
Thus, I argue that the judiciary converges on a set of institutional norms and preferences in response to the preferences of the institutions and networks, or "audiences," with which judges interact, both individually and institutionally, and these norms and preferences shape the judiciary's behavior towards the regime. The audience-based explanation incorporates insights from, and corrects shortcomings of both interest-oriented and ideas-oriented explanations. It demonstrates how the judiciary's relationship with the regime shapes institutional norms and preferences, which often explain judicial behavior better than rational calculations about risks to the judiciary's policymaking authority. The effect of this relationship on the norms and preferences of the judiciary can explain judicial assertiveness against an authoritarian regime, even when the judiciary's policy-making authority is at risk, or judicial support for a regime, even when this support restricts the judiciary's own policy-making authority. Variation in institutional interlinkages improves upon ideas-oriented historical institutionalist explanations, developing a generalizable framework for explaining variation in the ideas shaping judicial outcomes across authoritarian regimes.

\section{Pakistan: From Loyalty to Competition}

Pakistan has been ruled by the military for much of its history (1958-1972, 1977-1988 and 19992008). ${ }^{26}$ In this study, I compare three periods of military rule in Pakistan's history: the regimes of Ayub Khan (1958-1968), Zia-ul-Haq (1977-1988), and Pervez Musharraf (1999- 2008). Under Ayub, the judiciary was a Loyal Court, using its powers to uphold and legitimize the actions and authority of the regime. Under Zia, the judiciary was a Controlled Court, reading its own role and jurisdiction narrowly to avoid challenging the regime. Under Musharraf, the judiciary was a 
Competitive Court, and the regime found it progressively more difficult to ensure the judiciary's compliance, as the judiciary expanded its powers to compete with the regime, and ultimately clashed directly with the regime. Table 2 outlines the variation in institutional interlinkages across these regimes, which, I argue, explain variation in judiciary-regime relationships. In this cross-temporal analysis, I show how changes in the demographics, training, socialization and appointment processes of judges over time, reduced interlinkages between each regime and the judiciary and altered the audiences shaping judicial norms and preferences. This, I argue, explained the judiciary's shift from loyal collaboration under Ayub to competition and confrontation under Musharraf.

Table 2: Judicial-Regime Relationships Across Pakistan's Regimes

\begin{tabular}{|l|l|l|l|}
\hline & Ayub Khan Regime & Zia-ul-Haq Regime & $\begin{array}{l}\text { Pervez Musharraf } \\
\text { regime }\end{array}$ \\
\hline $\begin{array}{l}\text { Utilitarian } \\
\text { Interlinkages }\end{array}$ & Yes & Yes & No \\
\hline $\begin{array}{l}\text { Normative } \\
\text { Interlinkages }\end{array}$ & Yes & No & No \\
\hline Court Type & Loyal Court & Controlled Court & Competitive Court \\
\hline
\end{tabular}

\section{The Loyal Court under Ayub Khan - 1958-1968}

Ayub Khan was Pakistan's first military ruler, and during his regime, the judiciary was a loyal collaborator, upholding and legitimizing military dominance in Pakistan's political order. I argue that this loyalty was a product of an institutional norm of collaboration with, and deference to, the military, entrenched during this period. Under Ayub, the judiciary was appointed by the regime, and from a bureaucratic and legal elite that was closely tied to the military elite. The 
regime was the key audience shaping judicial norms and preferences, ensuring judicial loyalty. In 1958, Ayub Khan, the Chief of Army Staff, declared martial law, ousting the federal and provincial parliaments and governments, and abrogating the constitution. Within a month, in the judgment Dosso v State, the Supreme Court validated the proclamation of martial law, and also held that the regime's authority and orders were immune judicial scrutiny. ${ }^{27}$ Over the next few years, the judiciary, in its judgments, showed "remarkable faith in the regime's pursuit of the common good. ${ }^{28}$ Even after the regime introduced a new constitution in 1962 and restored fundamental rights, courts continued to uphold the regime's executive prerogatives, while developing some procedural checks on the regime's actions. ${ }^{29}$ The judiciary collaborated in the regime's suppression of left-wing and nationalist political parties, and set lenient procedural standards for legislative and executive actions, including detaining political leaders. ${ }^{30}$

This support for the regime could not simply be explained by strategic acquiescence to a powerful regime. Strategic judges seeking to avoid confronting the regime had options other than upholding the regime's authority. The high courts had the discretionary authority to avoid taking up legal questions that directly concerned the military's authority. In Dosso v State (1958), the Court simply had to determine whether a set of criminal regulations continued to apply after the abrogation of the constitution, but the Court chose to use the petition as a vehicle for legitimizing the coup. In Dosso and subsequent judgments, the courts upheld the policies and discretion of the regime, defending the merits, principles and necessity of these policies. The manner in which the judiciary used its powers and discretion, indicates that strategic caution was not the only motivation for supporting the regime.

Outside the courts, there is also evidence that judges did not simply acquiesce to the regime's authority. Senior judges were also the architects of the constitutional framework that 
provided the regime with unbridled executive power, and acted as legal advisers to the military regime. ${ }^{31}$ This was not simply a case of judicial deference, as judges actively assisted the regime in legitimizing and expanding the regime's powers.

Therefore, I argue, the pro-regime inclination of the judiciary is best explained by the institutional norms and preferences of the judiciary, shaped by its institutional interlinkages with the regime. The institutional interlinkages between the civil-military bureaucracy and the judiciary ensured the regime was a critical audience in shaping judicial norms and preferences, and served to reproduce a pro-military inclination within High Courts.

The first institutional interlinkage is the regime's utilitarian interlinkage with the institutional hierarchy of the judiciary, determining appointments and promotions. The judges of the High Courts were appointed by the President in consultation with the Chief Justice of Pakistan and the Chief Justice of the High Court. In practice, judges were unlikely to recommend someone who the President was likely to reject, and the President could ignore the recommendations of Chief Justices and select his own candidates, often from the executive bureaucracy. ${ }^{32}$ Ayub personally interviewed candidates short listed for high courts appointments, and rejected candidates for arbitrary reasons..$^{33}$ Thus, Ayub's regime played the primary role in judicial appointments and promotions, and ensured that judges who were appointed and rose up the ranks, were those likely to decide in support of the regime.

"There was no real gap between the judiciary and the military. To become a judge, you spent your time ingratiating yourself to the establishment [a popular term for the nexus of the military and civilian bureaucracy]. Very few lawyers seeking judicial appointments would be out there agitating against the regime." 34 
The second institutional interlinkage with the regime was the pool from which judges were recruited. The judiciary arrived in three streams - from the federal Civil Service trained in the British- run Civil Service before independence, from the judicial services of the subordinate judiciary which was also fused with the provincial bureaucracies, and from lawyers, often trained in the United Kingdom. In the early years, members of Pakistan's bureaucracies and leading lawyers were typically from elite families, trained with the values and ruling practices of British colonial rule: executive discretion with limited accountability. ${ }^{35}$ Thus, judges worked and trained in a social and professional network that favoured executive discretion and was disdainful of populism and partisan politics. Both the bureaucratic and legal elite emerged from pre-existing established elite networks that were the primary beneficiaries of military and bureaucratic rule. Thus, the judiciary and the regime shared strong normative interlinkages during this period.

The key audiences for judges seeking to build a career and build esteem were the military regime and regime-appointed chief justices, the bureaucratic elite of the civil services, and the legal elite. Under this system, anti-regime judicial activism could hardly be expected or condoned. Those who desired to be appointed or promoted needed the approval of the regime, and those who desired to build esteem as judges within the legal and bureaucratic elite had to present their distance from partisanship and redistributive politics and support for executive maintenance of law and order. Thus, the internal consensus was that the judiciary would collaborate with the military regime, and consolidate its executive authority, while carving out a place for the judiciary within the political order as a venue for upholding procedural rights. This consensus primarily explained the judiciary's decision-making that did not just acquiesce to military dominance but served to legitimize and sustain it. One lawyer explained: 
"These judges...were the new colonial masters. For them the role of the court was a carry-over of the British court. More of a court that stressed law and order and stability, like a colonial judge...[T]he courts represented the interests of the military class."36

\section{The Controlled Court under General Zia-ul-Haq: 1977-1988}

Zia-ul-Haq was Pakistan's longest-ruling military ruler. After initial friction between his regime and the judiciary, the judiciary was deferential and submissive to the regime, readings its own jurisdiction narrowly, and avoiding any clashes with this regime. I argue that this deference was a product of an institutional norm of caution and submission that was entrenched during this period. Under Zia, the judiciary was increasingly recruited from networks of middle-class lawyers with fewer ties to the military elite, but the regime tightened its control over judicial careers to ensure the judiciary stayed under the regime's control.

When Zia came to power after ousting Pakistan's first elected civilian government, both the military and Supreme Court sought to construct a collaborative relationship similar to the one in place under Ayub Khan. When Nusrat Bhutto, the wife of the ousted Prime Minister, filed a petition in the Supreme Court challenging the legality of the coup, the Court validated the coup as "necessary" to resolve the crisis Zia's elected predecessors had created. ${ }^{37}$ The Court outlined a collaborative relationship, in which the regime was provided wide discretion to take actions deemed necessary to achieve its aims, and the judiciary had the power to determine the standard of necessity these actions had to meet.

But as the government grew more repressive, the younger judges of the High Courts increasingly diverged from the military regime over what actions were 'necessary' to achieve the 
regime's goals, and accepted petitions challenging the actions of the regime. The Sindh High Court objected to the detention of two former ministers of the ousted government, warned martial law authorities against detaining anyone without a trial, and placed limits on the regime's authority to violate fundamental rights beyond what was deemed "necessary." 38 Other high courts followed suit, setting aside convictions by military courts, and overturning detentions by martial law authorities. ${ }^{39}$ The regime could not tolerate this increasing divergence between the regime and the judiciary, and moved to take control of the judiciary.

In 1981, Zia introduced a Provisional Constitutional Order (PCO), that drastically weakened the judiciary and reshaped its composition to weed out all judges who would challenge the regime. Orders and actions taken by the regime were now considered to have been validly made and Zia ordered judges to take a new oath under the PCO, forcing them to recognize the PCO and the reduction of the judiciary's authority. Those judges who could not or would not take the oath, were automatically removed from the judiciary. Most judges were willing to take the oath and keep their jobs. ${ }^{40}$

From 1981 to 1985 , the superior judiciary largely surrendered to military control. Over the course of these five years, there were only thirty eight reported judgments pertaining to the military's prerogatives, a far cry from the period between 1977 and $1981 .{ }^{41}$ Few cases of constitutional importance were brought before High Courts, and those raising important constitutional questions were returned by courts or were never fixed for hearing before judges. Thus, the judiciary remained largely silent on the military regime's actions.

The judiciary's silence can be partly attributed to strategic caution in the face of an unfettered military dictator, as well as the loss of jurisdiction to actually issue judgments that challenged the regime. But the judiciary's approach also reflected the entrenchment of the 
judiciary's self-conception during this period as a submissive and deferential subordinate to military rule. Judges would seek out the advice of government lawyers on the powers of the judiciary, and whether there were challenges to the actions of the martial law authorities that it could even accept for hearing. ${ }^{42}$

"if someone had been arrested or detained, as a young activist lawyer I would to go the judges seeking relief from the courts. Informally, they would request the Advocate General or Assistant Advocate General for relief for the detainee, but they would refuse to hear these cases." ${ }^{\prime 3}$

Further, after Zia fully restored the jurisdiction of courts in 1985, and abolished military courts, the judiciary responded cautiously, first refusing to hear the growing number of petitions challenging past decisions by the former military courts, and only gradually accepting more petitions and asserting its authority. Even after Zia died and democracy was restored in 1988, the judiciary refrained from challenging the military, and was often accused of assisting the military in weakening civilian governments while shielding the military's prerogatives from civilian interference. ${ }^{44}$ Thus, this acquiescent approach to the military could not be explained solely by the context of jurisdictional constraints and strategic caution.

This norm of submission and deference came after Zia responded to the gradual divergence between the military and the judiciary by extending his control over the appointments and careers of judges. The diminishing of the judiciary's normative interlinkages with the regime explained the increasing divergence and the strained collaboration between the two institutions in the early years of Zia's regime. The normative interlinkages diminished for two reasons. First, the 1973 Constitution ended the recruitment of judges from the federal bureaucracies, which 
removed one key network of pro-military elites from the ranks of the judiciary. A majority of judges were now recruited laterally from the bar of practicing lawyers.

Second, the pool of practicing lawyers from which judges were recruited was itself changing. With the growth of commercial law, elite lawyers who previously populated high court benches were now gravitating towards the greater monetary rewards of commercial law, and "successful lawyers were unwilling to sacrifice this (to become judges)." 45 Conversely, for middle-class lawyers who could not get jobs in elite commercial firms, the salary and perks of a high court judgeship still promised social mobility and economic stability. These middle-class lawyers did not have the same elite ties with the military and bureaucratic elite as the postcolonial legal elite did, nor had they enjoyed the same benefits from military rule. Hence, the networks judges were recruited from were less tied to or supportive of military supremacy. ${ }^{46}$ Further, these lawyers were trained in local law schools, where procedural training steadily declined from the 1970 s onwards. ${ }^{47}$ Given the diminishing familiarity with procedure, lawyers who later became judges, focused on "appearing bold and effective among the lawyers" to develop their reputations. ${ }^{48}$ These judges cared more about pronouncing popular judgments rather than demonstrating legal and procedural expertise, as a means to cultivating a reputation with lawyers in courtrooms. ${ }^{49}$

Thus, fewer judges were recruited from the pro-military legal and bureaucratic elite, and most judges were recruited from a pool of middle-class lawyers, with fewer connections to the military elite. These judges were increasingly concerned about building a reputation within the bar through outcomes that were popular with lawyers. Thus, the normative interlinkages between the judiciary and the regime were declining, while the linkages between the judiciary and the bar were strengthening. 
Zia responded to the diminishing normative interlinkages by deepening the utilitarian interlinkages between the regime and the judiciary. Nearly all judges appointed under his civilian predecessor had either resigned or been removed when Zia purged the judiciary in $1981 .{ }^{50}$ The recruitment of judges was primarily in the hands of Zia and a handful of judges, lawyers and bureaucrats who had a close relationship with Zia and his junta. Lawyers had to stay in the "good books of the generals in power" to become judges. ${ }^{51}$ Thus, even as judges were increasingly appointed from the more independent bar of practicing lawyers, the regime appointed lawyers who were unwilling to "rock the boat" and had proven this through their time as government lawyers. ${ }^{52}$

Zia further enforced his control over the judiciary during this period through his powers to confirm judges. Only once a judge is confirmed is his or her tenure secured till retirement. The intended practice was that a judge was appointed as an ad-hoc judge before being confirmed within two years. However, Zia routinely violated this expectation, maintaining the ad-hoc status of judges, and only confirming appointments of High Court chief justices "in the last month or so of the appointments." $" 53$

"What can a judge do when the sword of confirmation hangs over his head? An Adhoc judge needs a lot of courage, sense of duty and high degree of idealism...to risk his job by annoying the powers that be." 54

Thus, the military-led executive strengthened utilitarian interlinkages with the judiciary, and those who moved forward in their judicial careers were those willing to acquiesce to the regime. This was the era of the controlled court in Pakistan, where a norm of submission to the will of the military dominated the judiciary's internal culture. A senior lawyer explained: 
“During Zia's time...[t]he judges were concerned: what does the military want? We do not want to offend the military." 55

\section{The Competitive Court under General Musharraf: 1999-2008}

Under General Musharraf, after an initial period of cautious deference, the judiciary grew progressively more assertive, expanding its jurisdiction and role in the political system and challenging the regime's core interests, leading to a confrontation between the regime and the judiciary. I argue this competition was a product of a shift in institutional norms towards judicial independence and role expansion within the political system. Under Musharraf, the judiciary was recruited from a network of lawyers with few ties to military elite, and the regime's control over judicial appointment was also diminished, as the judiciary consolidated control over the appointment process.

In October 1999, when General Musharraf seized power, the judiciary once more ruled on the validity of the military coup. In Zafar Ali Shah v Pervez Musharraf (2000), the Supreme Court heard a petition from a recently ousted parliamentarian challenging Musharraf's coup. Musharraf forced judges to swear an oath to the very Provisional Constitutional Order which was being challenged in this petition, and purged the judiciary of judges he feared might challenge the regime. A majority of judges took the oath in order to preserve their careers. ${ }^{56}$ Significantly, however, six justices of the Supreme Court, including the Chief Justice, refused to take the oath choosing to step down. The unprecedented en bloc refusal by Supreme Court judges demonstrated the growing independence of the judiciary from the military. The newly purged Court upheld the coup on similar grounds of necessity as had been used to uphold Zia's coup, 
and granted Musharraf wide discretionary powers. ${ }^{57}$ But the Court held that the judiciary maintained its powers of judicial review and enforcement of fundamental rights. It stated that the judiciary had a vital role in facilitating "economic growth and social development" and even held that it would overturn any validly passed constitutional amendment undermining judicial independence. Thus, the judiciary granted itself a far broader role than previous coup-validating judgments had done.

In Musharraf's early years, the judiciary did not contest the regime's political agenda and authority, but it emphatically protected its own jurisdiction and authority, and then asserted and expanded its role in questions of socio-economic justice, stretching its jurisdiction over the ruling military's growing real estate and commercial empire. For example, the high courts extended their jurisdiction over the land allocation decisions of the military's housing cooperation, and curtailed the discretionary powers of the military's cantonment administrative authorities. ${ }^{58}$ After 2005, this focus on socio-economic justice built up into an unprecedented phase of judicial activism, as the expansive role of the judiciary percolated upwards from the High Courts before being adopted by Chief Justice Iftikhar Chaudhry in the Supreme Court. The judiciary started challenging the military's core security prerogatives and primary governing agenda, including, most famously, overturning the privatization of Pakistan Steel Mills, a cornerstone of the regime's economic policy.$^{59}$

The figures below summarize and compare all reported military-related jurisprudence during the regimes of General Zia (1977-1988) and General Musharraf(1999-2008) (Coding is detailed in Appendix 1). ${ }^{60}$ Figure 1 shows that, year to year, the judiciary ruled against the military in a higher proportion of cases under Musharraf than under Zia, as the judiciary ruled against the military in a majority of the reported judgments almost every year under Musharraf. ${ }^{61}$ 
The graph also differentiates assertive jurisprudence of the two periods based on the military's three types of prerogatives. The first set of prerogatives include the military's control over its core structure and security mission. ${ }^{62}$ The second set deal with the military's economic assets and activities. ${ }^{63}$ The third set are political and policymaking prerogatives, including the granting of non-security executive, legislative and judicial functions to the military. The military is likely to be more protective of its security and economic prerogatives as these are crucial to maintaining its autonomy from other institutions. Therefore, military regimes are most likely to retaliate against challenges to these prerogatives. ${ }^{64}$ A controlled court would read its jurisdiction narrowly, avoiding challenging the ruling military's security and economic prerogatives. A competitive court would read its jurisdiction broadly, and be more willing to hold the ruling military's economic and security prerogatives up to judicial scrutiny. During Zia's regime, the controlled court did not assert itself against the military's economic and security prerogatives. Conversely, during Musharraf's regime, a majority of rulings against the military dealt with economic and security prerogatives, making the judiciary's challenges against the military during Musharraf's regime riskier. 
Figure 1: Comparing Judicial Assertiveness under Zia and Musharraf Regimes ${ }^{65}$
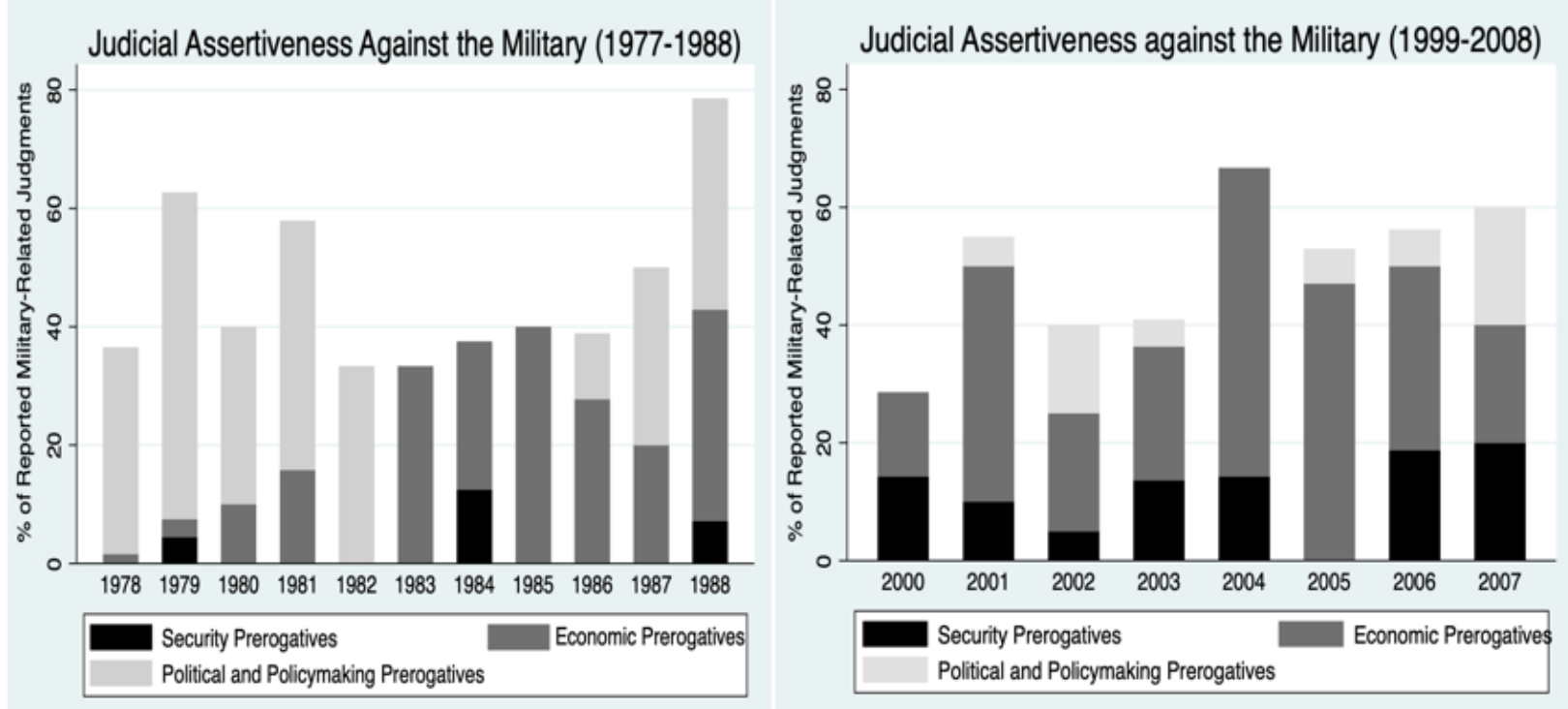

Further, in each judgment, the judiciary has three options: i) to uphold the military's action and authority, ii) to challenge the particular exercise of military power, but not the military's power to carry out such actions, and iii) to challenge the military's action and contest the authority of the military to carry out such actions. Figure 2 shows the judiciary increasingly willing to contest the military's prerogatives during Musharraf's regime. 
Figure 2: Comparing Judicial Contestation under Zia and Musharraf regimes
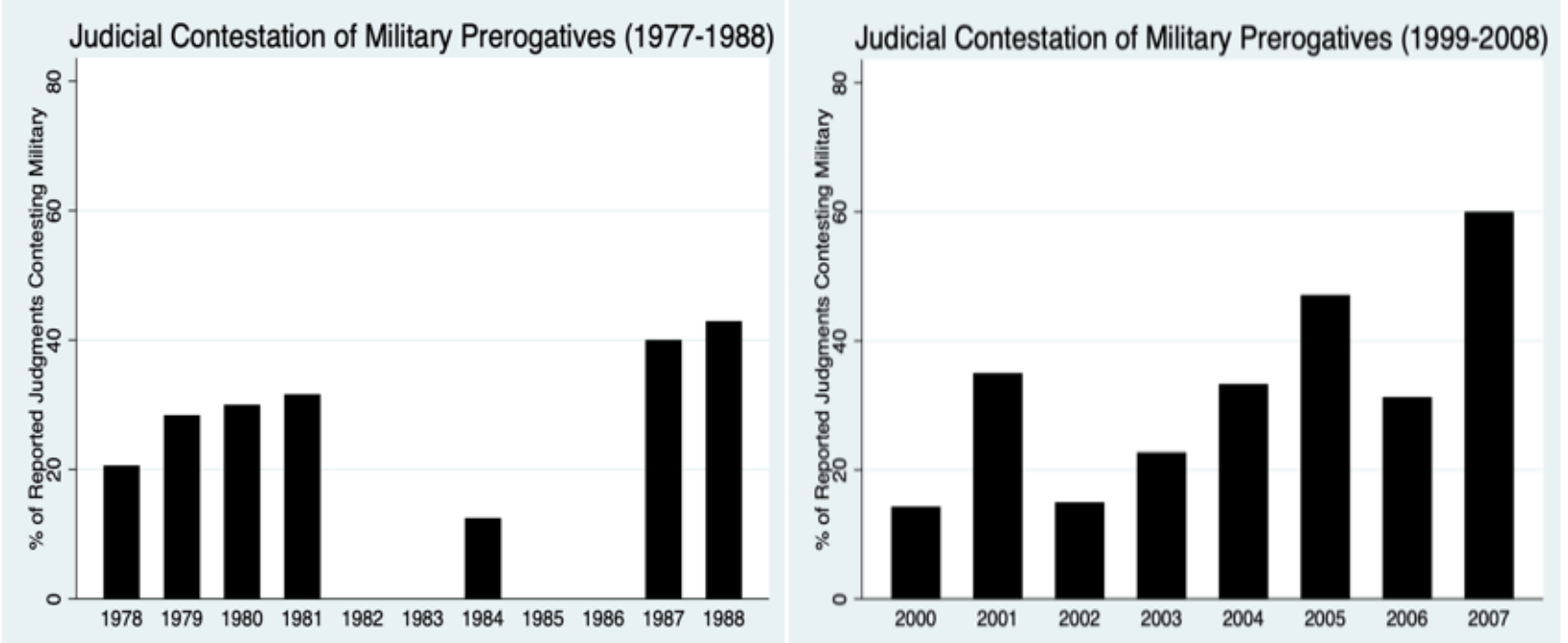

Thus, the judiciary was significantly more willing to issue rulings against the military, and contest the military's prerogatives during Musharraf's regime. This increasing assertiveness was risky and led to retaliation from the regime.

On March 8th 2007, the Supreme Court issued notice to the government regarding the recovery of people who had been missing after being detained by intelligence agencies ${ }^{66}$ The following day Musharraf pressured Chief Justice Chaudhry to resign, but Justice Chaudhry refused. Video and images of Musharraf ordering a defiant Chaudhry to resign, and later of security officials manhandling Chaudhry, spread across the media and became the catalyst for a nationwide backlash against Musharraf's regime led by the lawyers of the bar associations. ${ }^{67}$ The Lawyers' Movement, as it came to be known, turned the dismissal of the Chief Justice into a massive public controversy that dominated the headlines for months. In June 2007, the Court rejected the dismissal of the Chief Justice and ordered his reinstatement, adding that, for the judiciary, "The time has come to put the nation on a right path...so as to strengthen the country 
and to remove all excessive and colourable exercise of power in...every sphere of government." 68 The Court overturned the actions of the military dictator, and articulated a broad mission for the judiciary to save and transform the country.

After Chaudhry's return, the judiciary grew more assertive, challenging the regime's core interests regularly. Between August and November 2007, the courts began hearing cases pertaining to the exile of Musharraf's political opponents, political deals being made by the regime with political parties, security operations being carried out by the military, and even Musharraf's right to retain the Presidency while he remained Chief of Army Staff. ${ }^{69}$ In response, the regime declared a state of emergency, and a new Provisional Constitutional Order (PCO) was announced, and judges were once more asked to take a new oath under the new PCO. This time, in an unprecedented show of defiance, $63 \%$ of the superior court judges refused to take the oath, leading to the largest purge of the judiciary in Pakistan's history. ${ }^{70}$ Musharraf 's actions backfired and unprecedented agitation on the streets grew, as lawyers, civil society activists, and political parties resisted curfews and arrests and continued to pour out on the streets calling for a return to democratic rule. Thus, Musharraf, whose regime seemed so stable a year earlier, was forced out of power by 2008 , as a result of a confrontation with a competitive and unyielding judiciary.

The judiciary's progressively increasing assertiveness can be partly attributed to the activist leadership of Chief Justice Iftikhar Chaudhry, but it was by no means solely his leadership that reshaped the judiciary. ${ }^{71}$ The high courts were already expanding the judiciary's role and intervening in socio-economic issues, including regulating the economic interests of the military before Chaudhry became Chief Justice. Nor was this assertiveness merely a response to regime weakness or fragmentation. The regime was less centralized than Zia's regime, but was 
stable when the judiciary began directly challenging the regime in 2006, with Musharraf's political allies firmly in control of the parliament, and his political opponents vanquished and mostly in exile. ${ }^{72}$

This growing assertiveness was the product of the diminished role of the regime and its allies as key audiences shaping the norms and preferences of the judiciary. Under Musharraf, a competitive court emerged, with limited institutional interlinkages between the judiciary and the regime. The regime's utilitarian interlinkages with the judiciary were now limited, as the chief justices gained formal primacy in the judicial appointment process. ${ }^{73}$ In the preceding democratic decade, the fragmented political environment enabled the judiciary to gain new relevance as a site for settling political disputes between the prime minister and presidency. The Supreme Court took advantage of this new relevance and fragmented political environment to reinterpret the 'consultation' process between the chief Justice and the President in judicial appointments, determining that the President was bound to accept the advice of the chief justice on judicial appointments. ${ }^{74}$ During Ayub and Zia's regime, when vacancies opened in a High Court, the Chief Justice of that High Court and the provincial and federal government, would prepare a short-list of names for elevation to the bench, and the Chief Justice of Pakistan would recommend names from the list to the President. But the President could ignore or bypass the recommendations of the Chief Justice, and make his own selection, which he usually did. However, during Musharraf's regime, when the Chief Justices of the High Court, in consultation with the Law Ministry, would prepare a list of names for elevation to the bench, the Chief Justice of Pakistan would select names from that list, and the President was bound to implement the selection made by the Chief Justice. Thus, now the Chief Justices of the High Courts and Supreme Court had the primary role in the selection of judges. 
In appointing a judge from the bar, judges typically selected lawyers who had developed two types of reputation: i) with the judges themselves, and ii) with senior and influential lawyers with which the judges had ties. One judge explained that during the previous regimes "Uniformed and bureaucratic contacts were useful" but with the change in the judicial appointment process, the development of a "professional reputation as a lawyer" gained importance in the selection process, which meant building a reputation with High Court judges and senior lawyers, became crucial. ${ }^{75}$ Thus, judges gained primacy in the judicial appointment process, and the independent and politically active bar associations developed an informal role, while the role of the executive was reduced, weakening utilitarian interlinkages between the bench and the regime.

The normative interlinkages between the regime and judiciary had already decreased since the 1970s, as the judiciary was increasingly recruited from networks of middle-class lawyers that populated the bar associations. These interlinkages were strengthened during the democratic decade, as bar associations grew increasingly outspoken in their support for an activist judiciary that expanded its role in the political system, confronted executive power (civilian or military), and facilitated socio-economic justice. Judges seeking the esteem of bar associations through the outcomes of their judgments, had to at least pay lip service to the norms of the bar associations. During Musharraf's regime, the bar associations did not acquiesce to military dominance, and openly campaigned against judges deemed to be collaborators with the regime. ${ }^{76}$ They refused to appear before judges who upheld the regime's agenda, and published papers calling out judges who had 'bad reputations," naming and shaming them for corruption and complicity. ${ }^{77}$ Thus, bar associations exercised their power over judges' reputations, to pressure the judiciary into acting in line with the activist norms and preferences of the bar. ${ }^{78}$ As a 
former judge explained, "Who is a judge's audience? It is basically first the lawyers."79

Under Musharraf, the judiciary's increased assertiveness, and clashes with the regime can be best explained by the audiences shaping judicial norms and preferences. Over time, as institutional interlinkages between the judiciary and the regime diminished, and the bar's role as an audience shaping judicial norms and preferences grew, the judiciary pursued a more ambitious and expansive political and policy-making agenda, placing it at odds with the regime on major issues. ${ }^{80}$ Thus, the events of 2007 that helped bring down the military regime, can best be understood as products of diminished institutional interlinkages between the regime and the judiciary. This competitive court was not loyal to or dependent upon the military, and pursued an expanded role in Pakistan's political system, asserting itself against the regime and defying it at great political risk, triggering a dramatic clash between the courts and the regime.

\section{Applying the Audience-Based Framework Beyond Pakistan:}

In this section I briefly explore how the audience-based approach to explaining variation in judicial assertiveness against authoritarian regimes can be applied beyond Pakistan. The interlinkages between the superior judiciary and the regime in different authoritarian systems explains varying patterns of judicial assertiveness, as illustrated below. 
Table 3: Judicial-Regime Interactions Across Authoritarian Regimes

\begin{tabular}{|c|c|c|c|}
\hline & \multicolumn{3}{|c|}{ Normative Interlinkages } \\
\hline \multirow{3}{*}{$\begin{array}{l}\text { Utilitarian } \\
\text { Interlinkages }\end{array}$} & & $\begin{array}{l}\text { Yes } \\
\text { (Social and/or Professional } \\
\text { Networks are Recruited } \\
\text { from are Aligned with the } \\
\text { Regime) }\end{array}$ & $\begin{array}{l}\text { No } \\
\text { (Social and/or Professional } \\
\text { Network Judges are Recruited } \\
\text { from are not Aligned with the } \\
\text { Regime) }\end{array}$ \\
\hline & $\begin{array}{l}\text { Yes } \\
\text { (Appointing } \\
\text { Authority/s Aligned } \\
\text { with the Regime) }\end{array}$ & $\begin{array}{l}\text { Loyal Court } \\
\text { (Indonesia 1971-1998) }\end{array}$ & $\begin{array}{l}\text { Controlled Court } \\
\text { (Nigeria 1970s) }\end{array}$ \\
\hline & $\begin{array}{l}\text { No } \\
\text { (Appointing } \\
\text { Authority/s } \\
\text { Independent from } \\
\text { the Regime) }\end{array}$ & $\begin{array}{l}\text { Collaborative Court } \\
\text { (Turkey 1960s) }\end{array}$ & $\begin{array}{l}\text { Competitive Court } \\
\text { (Spain } 1960 \text { to } 1975 \text { ) }\end{array}$ \\
\hline
\end{tabular}

Under the regime of General Suharto, Indonesia's superior judiciary characterized a loyal court.

This loyalty was a product of deep institutional interlinkages between the regime and judiciary. Suharto's Ministry of Justice had direct control over judicial appointments and promotions and it used loyalty to the regime's integrationist ideology as a key criterion for promotions to attractive positions. Most judges were recruited from the close-knit Javanese bureaucratic elite that were beneficiaries of Suharto's regime, and Suharto coopted the Judges' Association, to which most judges belonged. ${ }^{81}$ Thus, through close utilitarian and normative interlinkages, the regime became the primary audience shaping judicial norms and preferences. The result was a loyal judiciary that actively endorsed Suharto's integrationist ideology and granted the regime almost 
unchecked power and authority. Even after Suharto's fall in 1998 in the face of widespread domestic opposition, the judiciary remained unwilling to assert itself against Suharto's regime, leading to growing calls for urgent and drastic judicial reform. ${ }^{82}$

Nigeria's superior judiciary was a controlled court under the military dictatorships of the 1970s and 1980s. Judicial officers were appointed by the President of Nigeria and the state governors on the recommendations of their State Judicial Commissions which were appointed by the Governors. The President and Governors had both powers of appointment and removal of judges. Nigeria's military dictators frequently used these powers to remove judges who were hostile to their interests. Thus, the utilitarian interlinkages between the regime and the judiciary ensured a silent submissive judiciary. ${ }^{83}$

Through the 1960s, the Turkish superior judiciary was a collaborative court. The military, bureaucracy, Republican Party, universities and judicial community, comprised what Belge (2006) calls the Republican alliance. They adhered to the Kemalist republican principles of secular top-down modernization and sought to place limits on majoritarian institutions where left-wing and identity based political parties could undermine this political project. ${ }^{84}$ Through a Kemalist legal education and the bureaucratic judicial structure, Kemalist norms and preferences were reproduced in the professional networks staffing the judiciary, and judges seeking to build esteem within these networks would adhere to these Kemalist norms ${ }^{85}$ Accordingly, after the coup of 1960, when the military regime established the Turkish Constitutional Court, the Court used its powers expansively as the guardian of the regime's ideological agenda. ${ }^{86}$ It acted assertively to protect the autonomy of republican state institutions and universities from political interference, while restricting the liberties of left-wing and identity-based political groups. ${ }^{87}$ Close normative interlinkages between the Republican elites and the judiciary, ensured both 
regime and judiciary collaborated in upholding the Kemalist political agenda.

In the later years of General Franco's authoritarian regime, the Spanish judiciary was a competitive court, in which judges challenged the regime even at great personal and professional risk. Under Franco, regime control over the appointment process was limited, as the selection of new judges was largely entrusted to the judiciary itself. ${ }^{88}$ Further, in the 1960 s, the legal community within Spain increasingly endorsed new norms of democracy and human rights. These norms diffused into the legal community through its ties to a liberalizing Catholic church, opposition parties within Spain, and activist lawyers and judges in neighbouring democratic European states ${ }^{89}$ Thus, the regime's limited control of the judicial appointment process and the growing support for democratic and human rights within the networks from which judges were recruited, led to the emergence of a competitive court in Spain. In his survey of Spanish judges in the 1970s, Toharia (1975) found that a majority of judges had an understanding of statesociety relations that was considerably at odds with the ideology of the Franco regime. ${ }^{90}$ By the 1970s, a growing a number of judges belonging to the pro-democracy professional association, Justicia Democratia, took up important positions within the judiciary, and the judiciary became a site for high-risk assertiveness against the Franco regime. ${ }^{91}$

Thus, the audience-based framework provides us the analytical tools to understand patterns of interaction between the judiciary and a wide range of authoritarian regimes. It explains why some judiciaries are willing to act assertively against authoritarian regimes, even in the absence of any clear political space or opportunities, while other judiciaries will support authoritarian regimes, even after the regimes weaken or are ousted from power. 


\section{Conclusion:}

In this article, I argue that the judiciary's affinity to authoritarian regimes diminishes as authorities and networks, or 'audiences', from which judges seek approval, to advance careers and build reputations, grow independent from the regime. The article devises a typology of judiciaries based on institutional interlinkages with authoritarian regimes. This typology connects the judiciary's norms and preferences with the regime's linkage to the promotion/selection process and its linkage to the pool from which judges are drawn. As we see in case studies from Pakistan and beyond, different configurations of institutional interlinkages between authoritarian regimes and judiciaries lead to variation in judicial assertiveness towards authoritarian regimes, as a consequence of the effect of these interlinkages on the norms and preferences of the courts.

This study adds to recent scholarship on judicial politics that calls for a reconsideration of judicial motivations beyond simply the realization of policy preferences. The analysis suggests that those interested in understanding judicial behavior in authoritarian settings should study the process of formation of judicial norms and preferences in relational terms, and consider how the institutional structure and sociological background of judges connect the judiciary with different audiences that shape their preferences. Therefore, it is not enough to either study the formal institutional structure of the judiciary or the social and professional networks of judges to understand judicial norms and preferences, and this framework brings both together to understand the development of judicial norms and preferences. In doing so, this article provides a comprehensive framework for explaining variation in judicial assertiveness both within and across authoritarian regimes. 
${ }^{1}$ In 2018, when the Maldives Supreme Court acquitted the increasingly authoritarian President Yameen's. political opponent, Yameen declared a state of emergency, and his security forces stormed the courts and arrested senior judges. JJ Robinson, “The Maldives Political Soap Opera Won’t End without Political Reform," Guardian, Feb. 7, 2018, https://www.theguardian.com/commentisfree/2018/feb/07/maldivespolitical-soap-opera-judicial-reform. Also see Lisa Hilbink, “The Origins of Positive Judicial Independence," World Politics 64 (October 2012), 587-621; H.P. Lee, Constitutional Conflicts in Contemporary Malaysia (Oxford: Oxford University Press, 2017).

${ }^{2}$ Hamid Khan, The History of the Judiciary in Pakistan (Karachi: Oxford University Press, 2016).

${ }^{3}$ Diana Kapiszewski, “Tactical Balancing: High Court Decision Making on Politically Crucial Cases,” Law and Society Review 45 (May 2011), 471-50.

${ }^{4}$ See Lawrence Baum, The Puzzle of Judicial Behavior (1997: Michigan University Press, Ann Arbor); Lee Epstein and Jack Knight, "Reconsidering Judicial Preferences," Annual Review of Political Science 16 (2013), 11-31; Lisa Hilbink, “The Constituted Nature of Constituents’ Interests: Historical and Ideational Factors in Judicial Empowerment," Political Research Quarterly 62 (December 2009), 78197; Patricia Woods and Lisa Hilbink, “Judicial Empowerment: Ideas and Interests," Political Research Quarterly 62 (December 2009), 745-52.

${ }^{5}$ Lisa Hilbink, Judges Beyond Politics in Democracy and Dictatorship (New York: Cambridge University Press, 2007); Patricia Woods, Judicial Power and National Politics (Albany: SUNY Press, 2009).

${ }^{6}$ The study is focused on superior judiciaries, and does not aim to explain judicial behavior in lower courts or subordinate judiciaries, which often have distinct relationships with other branches of government.

${ }^{7}$ I build on the 'audience' concept as developed by Baum. Lawrence Baum, Judges and Their Audiences (Ann Arbor: University of Michigan, 2007). 
${ }^{8}$ Woods (2009) and Ocantos (2014) highlight the role of social networks and informal relationships in the construction of judicial preferences. Woods, 2009; Ezequiel Gonzales Ocantos, "Persuade Them or Oust Them: Crafting Judicial Change and Transitional Justice in Argentina," Comparative Politics 46 (July 2014), 479-98.

${ }^{9}$ I conducted interviews with high court lawyers and retired judges. My sample included lawyers and judges who served or practiced under all three regimes. To protect anonymity, interviews with judges and lawyers are assigned the letters $\mathrm{J}$ and $\mathrm{L}$, respectively, and a random number between 1 and 100 generated and assigned to each interview. All interviews are referenced by that code, and the interview date.

${ }^{10}$ See Tamir Moustafa, The Struggle for Constitutional Power: Law, Politics and Economic Development in Egypt (New York: Cambridge University Press, 2007); Alexei Trochev, Judging Russia: Constitutional Court in Russian Politics 1990-2006 (New York: Cambridge University Press, 2008); Jennifer Widner, "Building Judicial Independence in Semi-Democracies: Uganda and Tanzania," in Tom Ginsburg and Tamir Moustafa, eds., Rule by Law: The Politics of Courts in Authoritarian Regimes (New York: Cambridge University Press, 2008), 124-43.

${ }^{11}$ Lee Epstein and Jack Knight, The Choices Justices Make (Washington D.C.: Congressional Quarterly, 1998); Georg Vanberg, "Constitutional Courts in Comparative Perspective: A Theoretical Assessment," Annual Review of Political Science 18 (2015), 167-85.

12 The interests-oriented perspective would predict that the judiciary would only act on its sincere preferences where the preferences of the judiciary and the regime aligned, or on questions not salient for the regime. Gretchen Helmke, Courts under Constraints: Judges, Generals and Presidents in Argentina (New York: Cambridge University Press, 2005); Gretchen Helmke, "Regimes and the Rule of Law: Judicial Independence in Comparative Perspective," Annual Review of Political Science 12 (2009), 346366; Julio Rios-Figueroa, "Fragmentation of Power and the Emergence of an Effective Judiciary in Mexico," Latin American Politics and Society 49 (Spring 2007), 31-57. 
${ }^{13}$ For a detailed critique of limitations of the interest-based approach to explaining high-risk judicial assertiveness, see Hilbink, 2012; Matthew Ingram, Crafting Courts in New Democracies: The Politics of Subnational Judicial Reform (New York: Cambridge University Press, 2015).

${ }^{14}$ See Hilbink, 2007; Hilbink, 2012; Rogers Smith, "Historical Institutionalism and the Study of Law," in Keith Whittington, R. Daniel Keleman, and Gregory Caldeira, eds., Oxford Handbook of Law and Politics (Oxford: Oxford University Press, 2008), 46-82.

${ }^{15}$ Javier Couso and Lisa Hilbink, "From Quietism to Incipient Activism: The Institutional and Ideological Roots of Rights Adjudication in Chile," in Gretchen Helmke and Julio Rios-Figueroa, eds., Courts in Latin America (New York: Cambridge University Press, 2011), 99-127; Diana Kapiszewski, “How Courts Work: Institutions, Culture and the Brazilian Supremo Tribunal Federal,” in Javier Couso, Alexander Huneeus, and Rachel Sieder, eds., Cultures of Legality: Judicialization and Political Activism in Latin America (New York: Cambridge University Press, 2010).

${ }^{16}$ James March and Johan Olsen, "The Logic of Appropriateness,” in Robert Goodin, ed., Oxford Handbook of Political Science (Oxford: Oxford University Press, 2011).

${ }^{17}$ For a detailed critique and a generalizable framework for explaining variation and change in judicial ideology in democracies, see Erik Bleich, "Historical Institutionalism and Judicial Decision-Making: Ideas, Institutions and Actors in French High Court Hate Speech Rulings,” World Politics 70 (January 2018): 53-85. This project builds on this agenda, developing a generalized framework for explaining variation in judicial ideology in authoritarian regimes.

${ }^{18}$ Baum, 2007.

${ }^{19}$ Lee Epstein and Jack Knight, 2012; Tom Ginsburg and Nuno Garoupa, Judicial Reputation: A Comparative Theory (Chicago: University of Chicago Press, 2015).

${ }^{20}$ Baum, 2007.

${ }^{21}$ See Ginsburg and Garoupa, 2015.

22 The concept of institutional interlinkages is adapted from the study of interlinkages between international institutions in global governance that explains the transmission of global norms across 
international institutions. The literature on global climate governance and energy policy uses a typology for institutional interlinkages which I adapt. Andreas Goldthau, The Handbook of Global Energy Policy (Oxford: John Wiley and Sons, 2013); Olav Stokke, “The Interplay of International Regimes: Putting Effectiveness Theory to Work" (Lysaker: The Fridtjob Nansen Institute, 2001).

${ }^{23}$ By judicial norms and preferences, I refer to the consensus view within the judiciary regarding policy preferences, judicial prerogatives and judicial role conception. See Hilbink, 2007; Ezequiel Gonzales Ocantos, Shifting Legal Visions: Judicial Change and Human Rights Trials in Latin America (New York: Cambridge University Press, 2016).

${ }^{24}$ See Ran Hirschl, Towards Juristocracy (Cambridge: Presidents and Fellows of Harvard College, 2004).

${ }^{25}$ Woods, 2009.

${ }^{26}$ Pakistan is a common law country. Its superior judiciary is composed of a Supreme Court and several High Courts. The courts carry out judicial review and have discretion over their caseload.

${ }^{27}$ State v Dosso 1958 PLD SC 533; The Province of East Pakistan v Md. Mehdi Ali Khan Panni, PLD 1959 SC 387.

${ }^{28}$ Paula Newberg, Judging the State: Courts and Constitutional Politics in Pakistan (Cambridge: Cambridge University Press, 1995), 101.

${ }^{29}$ See Saiyid Abul a la Maudoodi, et al. v The Government of West Pakistan and the Government of Pakistan, PLD 1964 SC 673.

${ }^{30}$ Malik Ghulam Jilani v Government of West Pakistan, PLD 1967 SC 33.

${ }^{31}$ Rashed Rahman, “Judiciary’s Role in Pakistan,” News, Jan. 7, 1993.

${ }^{32}$ Multiple interviewees said that, under Ayub, the practice of consultation sometimes simply involved informing the Chief Justice of the President's choice beforehand.

${ }^{33}$ Hamid Khan, “Judiciary - Institution in Decay - I,” Dawn, Oct. 14, 1994.

${ }^{34}$ Interview No. L-3, May $22^{\text {nd }} 2016$.

${ }^{35}$ See Ralph Braibanti, "Public Bureaucracy and Judiciary in Pakistan,” in Joseph LaPalombara, ed., Bureaucracy and Political Development (Princeton: Princeton University Press, 1967), 360-440. 
${ }^{36}$ Interview No. L-42, April $1^{\text {st }}, 2017$.

${ }^{37}$ Begum Nusrat Bhutto v The Chief of Army Staff and Federation of Pakistan, PLD 1977 SC 657.

${ }^{38}$ Mumtaz Ali Bhutto v The Deputy Martial Law Administrator, Section 1, Karachi, PLD 1971 Karachi 307.

${ }^{39}$ Syed Essa Noori v Deputy Commissioner, Turbat and 2 others, PLD 1979 Quetta 189.

40 “SC and High Courts' Judges Sworn In,” Dawn, Mar. 26, 1981.

${ }^{41}$ I collected military-related reported judgements from the following law reporters: Pakistan Law

Decisions (PLD), Pakistan Law Journal (PLJ), Supreme Court Monthly Report (SCMR), Civil Law Cases (CLC), Pakistan Criminal Law Journal (PCrLJ), Yearly Law Review (YLR), Pakistan Law Commission (PLC), Kew Law Reports (KLR) and Sindh and Balochistan Law Review (SBLR).

42 “Courts Powerless to Review ML Orders,” Star, May 11, 1983.

${ }^{43}$ Interview No. L-11, November $26^{\text {th }} 2016$.

${ }^{44}$ See Osama Siddique, “The Jurisprudence of Dissolutions: Presidential Power to Dissolve Assemblies under the Pakistani Constitution and Its Discontents," Arizona Journal of International and Comparative Law 23 (Fall 2006): 622-715.

${ }^{45}$ Interview No. J-65, March $14^{\text {th }}, 2017$.

${ }^{46}$ This change explains the difference between jurisprudence of the junior judges of the High courts appointed after Ayub's regime, and of the senior judges of the Supreme Court appointed earlier.

${ }^{47}$ See Osama Siddique, "Legal Education in Pakistan: The Domination of Practitioners and the 'Critically Endangered’ Academic,” Journal of Legal Education (February 2014), 499-511.

${ }^{48}$ Interview No. J-33, March $21^{\text {st }}, 2017$.

${ }^{49}$ As elite lawyers, who were often trained abroad, gravitated towards commercial law, the middle-class lawyers who increasingly populated the bench could not afford a foreign education, and thus were usually locally educated.

${ }^{50}$ Hamid Khan, “Judiciary - Institution in Decay - I,” Dawn, Oct. 14, 1994.

${ }^{51}$ Ibid. 
${ }^{52}$ Ibid.

${ }^{53}$ Abdullah Jan, "More than Half of PHC Judges Serving on an Adhoc Basis," News, March 10, 1995.

${ }^{54}$ Sarmad Ali, “The Judiciary and Social Change,” Muslim, Jul. 21, 1991.

${ }^{55}$ Interview No. L-5, May $15^{\text {th }} 2017$.

${ }^{56}$ Ashraf Mumtaz, "89 Superior Court Judges Take Oath under PCO: Two Judges of LHC Stand Retired," Dawn, Jan. 27, 2000.

${ }^{57}$ Syed Zafar Ali Shah v Pervez Musharraf, 2000 PLD SC 869.

${ }^{58}$ Cantonments are permanent military stations that also include expansive military-run residential areas, where thousands of civilians live. Pakistan Defence Officers' Housing Authority v Shamim Khan, 2005 PLD SC 792; Clifton and Defence Traders' Welfare Association v President, Clifton Cantonment Board, 2003 PLD 495.

${ }^{59}$ Abdullah Baloch v Federation of Pakistan, 2006 PLD Karachi 584. Shoaib Ghias, "Miscarriage of Chief Justice: Judicial Power and the Legal Complex in Pakistan Under Musharraf," Law and Social Inquiry 25 (Fall 2010): 985-1022; Maryam Khan, “Genesis and Evolution of Public Interest Litigation in the Supreme Court of Pakistan: Toward a Dynamic Theory of Judicialization," Temple Journal of International and Comparative Law 28 (Fall 2014), 285-359.

${ }^{60}$ Military-related jurisprudence $(n=359)$ includes judgments dealing with petitions challenging the actions and authority of the military and its subsidiary institutions. I focus on this jurisprudence, as both regimes were led by the military. Therefore, judgments that were more salient for the regime were those directly related to the military's prerogatives

${ }^{61}$ Barring 1978-1979, the judiciary also accepted a higher number of military-related petitions under Musharraf.

${ }^{62}$ These judgments deal with the military's control over formulating national security policy and carrying out security operations, and oversight of the security forces involved in carrying out this mission.

${ }^{63}$ Pakistan's vast military economy comprises public sector organizations, commercial subsidiaries and a vast real estate empire. 
${ }^{64}$ See David Pion-Berlin, "Military Autonomy and Emerging Democracies in South America," Comparative Politics 25 (October 1992), 83-102.

${ }^{65}$ I restrict the comparison to full years of military rule, so the proportions of military-related judgments can be fairly compared year to year. I omit 1977 and 1999 as the regimes entered power in the second halves of these years and 2008, as Musharraf's regime gave up power in the first half of the year. 66 “199 Persons Still Missing, SC Told,” News, Mar. 9, 2007.

${ }^{67}$ See Khan 2014; Sahar Shafqat, "Civil Society and the Lawyers' Movement of Pakistan," Law and Social Inquiry 43 (Summer 2018), 889-914.

${ }^{68}$ Mr. Justice Iftikhar Muhammad Chaudhry v President of Pakistan, 2007 PLD SC 578.

69 “Nawaz Can Come Back Anytime: SC,” News, Oct. 31, 2007; “Agencies Holding Missing Persons: CJ," News, Oct. 30, 2007; "Verdict in Musharraf Case Likely in 10-12 Days: SC," News, Oct. 19, 2007. 70 “Majority of Judges Refuse to Take Oath under New PCO,” News, Nov. 4, 2007.

${ }^{71}$ See Moeen Cheema and Gilani, eds., The Politics and Jurisprudence of the Chaudhry Court (Karachi: Oxford University Press, 2015).

${ }^{72}$ See Christophe Jaffrelot, The Pakistan Paradox: Instability and Resilience (London: Hurst and Co., 2015).

${ }^{73}$ Al-Jehad Trust v Federation of Pakistan, PLD 1996 SC 324.

74 The weak and fragmented ruling political parties of this period unsuccessfully sought to build institutional interlinkages and reshape the internal culture of the judiciary. See Khan, 2016.

${ }^{75}$ Interview No. J-19, April $23^{\text {rd }} 2017$.

${ }^{76}$ This opposition developed during Zia's regime when the bar became a crucial site for anti-regime activity, as junior lawyers used bar associations to mobilize against the repression of the regime. 77 “Judiciary Helping Military Government: SCBA,” Dawn, Nov. 7, 2002; “Closure of SCBA Offices Challenged," Dawn, Jul. 20, 2003; “SCBA to Publish White Paper on Judges,” News, Jun. 11, 2003. ${ }^{78}$ The extent of the bar association's influence can be seen from how senior judges sought to defend proregime decisions by claiming support from senior lawyers, leading one lawyer to comment on how judges 
are not guided by law but by 'certification' from the bar. Farhatullah Babar, "SC and the Bar," Nation, Nov. 5, 2002.

${ }^{79}$ Interview No. J-15, April 1, 2017.

${ }^{80}$ International audiences, including donors and the international legal community, were historically removed from judicial politics in Pakistan, but the highly publicized clash between Musharraf and the Supreme Court drew widespread international support for the judiciary, possibly emboldening lawyers and civil society to sustain their mobilization in favour of the assertive court. See Jane Perlez, Pakistan Leader Backs Down and Reinstates Top Judge, New York Times, Mar. 15, 2009.

${ }^{81}$ Pompe, The Indonesian Supreme Court: A Study of Institutional Collapse (Ithaca: Cornell Southeast Asia Program Publications, 2005).

${ }^{82}$ See Marcus Mietzner, "Political Conflict Resolution and Democratic Consolidation in Indonesia: The Role of the Constitutional Court," Journal of East Asian Studies 10 (December 2010), 397-424.

${ }^{83}$ See Okechukwu Oko, "Seeking Justice in Transitional Societies: An Analysis of the Problems and Failures of the Judiciary in Nigeria," Brooklyn Journal of International Law 31 (2005), 9-82.

${ }^{84}$ Ceren Belge, "Friends of the Court: The Republican Alliance and Selective Activism," Law and Social Inquiry 40 (September 2006): 653-92.

${ }^{85}$ See Simone Benvenuti, “Judicial Training in Turkey in Light of Constitutional Traditions and Europeanization,” Journal of Civil Law Studies (December 2011), 309-30.

${ }^{86}$ See Hootan Shambayati and Esen Kirdis, “In 'Pursuit of Contemporary Civilization': Judicial Empowerment in Turkey," Political Research Quarterly 62 (Dcember 2009), 767-780.

${ }^{87}$ Belge, 2006.

${ }^{88}$ Jose Toharia, "Judicial Independence in an Authoritarian Regime: The Case of Contemporary Spain," Law and Society Review 9 (Spring 1975), 475-96.

${ }^{89}$ See Hilbink, 2012.

${ }^{90}$ See Toharia, 1975.

${ }^{91}$ See Hilbink, 2012. 
Appendix 1: Military-related jurisprudence under General Zia-ul-Haq (1977-1988) and General Pervez Musharraf (1999-2008)

Military-related jurisprudence refers to High Court and Supreme Court decisions reviewing laws pertaining to the military or actions taken by the ruling military under the regimes of General Zia-ul-Haq and General Pervez Musharraf. In order to qualify for this data-set, the case must challenge the interests or actions of the military and its subsidiary institutions. This criterion excludes judgments that may be based on military law, but in no way challenge the interests or actions of the military or its affiliated institutions. I code these judgments in three ways.

Each court decision can have three possible outcomes. The first outcome is that the court rules in favour of the military or its subsidiary institutions, not contesting the authority or actions of the military at all. The second outcome is that the court rules against that particular exercise of military power but does not challenge the military's power to carry out such actions. The third outcome is that the court rules against the military's action and shifts the authority of the military to carry out such actions either partially or completely to another civilian institution. I define the second and third categories as assertion, and I define the third category as contestation. A hypothetical example is useful to clarify the distinction between the three possible outcomes. The court has to rule on an appeal challenging a decision by the military's own court martial proceedings. The court has three options in the final judgment. 1) The court can dismiss the appeal, not challenging the actions or the authority of the military courts to make that decision. 2) The court can grant the appeal, ruling against the particular action taken by the military courts on procedural grounds (eg. the court did not carry out any evidentiary hearings during the proceedings), but not contesting the military court's authority to make such a decision. 3) The 
court can grant the appeal, ruling against the action taken by the military courts, on the determination that the appellant does not fall under the jurisdiction of the military courts, thus contesting the military court's authority to hear cases pertaining to this class of accused.

Accordingly, I first code decisions based on whether they qualify as assertion, i.e. whether they fall in the second and second third or not. Secondly, I code decisions based on whether they qualify as contestation, i.e. whether they fall into the third category or not.

Finally, I code decisions based on the military prerogative to which the decision pertains. By prerogative I mean a power or privilege the military presumes it has. There are three types of prerogative that Pakistan's military holds.

I) The Military's Control over its Security Structure and Mission: This includes judgments dealing with the military's control over formulating national security policy and carrying out security operations, and oversight of the forces involved in carrying out this security mission. II) The Military's Control over its Economic Assets and Activities: This includes judgments dealing with the vast economic assets of the military and its subsidiary institutions. Pakistan's military economy comprises three distinct segments: major public-sector organizations controlled by the army, the commercial subsidiaries that provide for the welfare of the army, and the vast real estate empire owned and administered by the army and a subordinate civilian bureaucracy. III) Military's Control over Politics and non-Security Policy-Making Activity: These are cases where the military played a role in or took over the policy-making and political branches of government, unrelated to security. Thus, it covers the granting of non-security executive, legislative and judicial functions to the military. The jurisprudence pertaining to these functions typically increases during periods of military rule, as the military intervenes in all institutions of 
governance. At the apex of the executive structure this includes formal seizures of executive power through military coups, and informal interventions in the political process to favour allied political parties. Below high-level political interventions, military officers are also recruited laterally into civilian bureaucracies. Legislatively, military regimes seek to create news laws and amend the constitution. And judicially, summary military courts have also been established to deal with criminal cases. 